\title{
Antibiotic Therapy, Endotoxin Concentration in Cerebrospinal Fluid, and Brain Edema in Experimental Escherichia coli Meningitis in Rabbits
}

\author{
Martin G. Täuber, Atef M. Shibl*, \\ Corinne J. Hackbarth, James W. Larrick, \\ and Merle A. Sande
}

\author{
From the Medical Service, San Francisco General Hospital, \\ and the Department of Medicine, University of California, \\ San Francisco; and the Cetus Immune Corporation, \\ Emeryville, Californio
}

\begin{abstract}
We investigated the effect of cefotaxime and chloramphenicol on endotoxin concentrations in cerebrospinal fluid (CSF) and on the development of brain edema in rabbits with Escherichia coli meningitis. Both antibiotics were similarly effective in reducing bacterial titers. Cefotaxime, but not chloramphenicol, induced a marked increase of endotoxin in CSF, from $\log _{10} 1.5 \pm 0.8$ to $\log _{10} 2.8 \pm 0.7 \mathrm{ng} / \mathrm{ml}(P<.01)$. This result was associated with an increase in brain water content $(405 \pm 12 \mathrm{~g}$ of water $/ 100 \mathrm{~g}$ of dry weight compared with $389 \pm 8 \mathrm{~g}$ in untreated controls; $P<.01$ ), whereas in animals treated with chloramphenicol, brain water content was identical to controls. The cefotaxime-induced increase in endotoxin concentration and brain edema were both neutralized by polymyxin B, which binds to the lipid A moiety of endotoxin, or by a monoclonal antibody to lipid A. These results indicate that treating gram-negative bacillary meningitis with selected antibiotics induces increased endotoxin concentrations in CSF that are associated with brain edema.
\end{abstract}

Bacterial meningitis remains a serious disease associated with high morbidity and mortality [1]. The infecting organism appears to be a major determinant of the prognosis [2], which is particularly grave in gram-negative bacillary meningitis $[3,4]$. Liberation of harmful bacterial products as a consequence of treatment is a possible explanation for an adverse outcome despite effective antimicrobial therapy. In experimental meningitis, fragments of the pneumococcal cell wall can induce profound inflammation $[5,6]$, increased intracranial pressure, and brain edema [7]. Furthermore, in vitro and in vivo experiments have demonstrated that some antibiotics liberate large amounts of endotoxin from gramnegative bacteria [8-10]. Endotoxin has been clearly linked to many of the systemic and local complications of gram-negative infections [11]. In gram-

Received for publication 24 February 1987, and in revised form 27 April 1987.

This work was presented in part at the 43rd annual meeting of the American Federation for Clinical Research, held in Washington, D.C., on 25 May 1986.

We thank Kenyon Scott, Todd Carpenter, and Felicia Stella for technical assistance.

Please address requests for reprints to Dr. Martin Täuber at his present address: Medizinische Poliklinik, University Hospital, Rämistrasse 100, 8091 Zürich, Switzerland.

*Present address: Department of Microbiology, King Saud University, Riyadh, Saudi Arabia. negative bacterial meningitis, endotoxin is consistently found in CSF at the time of diagnosis [12]. During therapy, endotoxin concentrations in the CSF decline progressively over a period of days, but the possibility of an initial rise of endotoxin, after instituting antibiotics, has not been excluded [12].

Endotoxin release from bacteria into CSF during treatment of gram-negative bacillary meningitis may induce harmful effects on the brain. The present studies were designed to determine whether antibiotic treatment induces an increase of endotoxin in CSF and whether this increase is associated with harmful pathophysiological effects in a model of Escherichia coli meningitis. Results demonstrate that endotoxin concentrations increased with one antibiotic but not a second antibiotic and that this increase was associated with the development of brain edema. This effect was aborted by polymyxin B, which binds to the active moiety of endotoxin (lipid A), and by monoclonal antibodies to lipid A.

\section{Materials and Methods}

Infecting organism. A K1-positive, serumresistant strain of $E$. coli, originally isolated from a neonate with meningitis, was used. The organism was stored on glass beads at $-70 \mathrm{C}$, grown overnight in tryptic-soy broth, and then washed and diluted in saline to the desired concentration. MIC/MBCs 
of the organism were $0.125 / 0.125 \mu \mathrm{g} / \mathrm{ml}$ for cefotaxime and $8 />64 \mu \mathrm{g} / \mathrm{ml}$ for chloramphenicol [13].

Model of experimental meningitis. We used a rabbit model of experimental meningitis, which was originally described by Dacey and Sande [14]. In brief, New Zealand white rabbits, $2-3 \mathrm{~kg}$, were anesthetized iv with $30 \mathrm{mg}$ of pentobarbital $/ \mathrm{kg}$ (Carter-Glogau Laboratories, Glendale, Ariz). A dental acrylic helmet was attached to the skull by using four screws; the helmet allowed the animals to be placed in stereotactic frames constructed to facilitate puncture of the cisterna magna. Three days after attachment of the helmet, the animals were again anesthetized with pentobarbital, and 5-7 $\times$ $10^{5} \mathrm{cfu}$ of logarithmically growing $E$. coli suspended in $0.3 \mathrm{ml}$ of saline were injected into the cisterna magna by using a spinal needle ( 3.5 inch, 25 gauge; Becton, Dickinson and Co., Rutherford, NJ). Sixteen hours later, long-lasting anesthesia was induced by iv infusion of $2 \mathrm{~g}$ of urethane $/ \mathrm{kg}$ (Sigma, St. Louis). The animals were placed in the stereotactic frames, the cisterna was punctured to collect the first sample of $0.3 \mathrm{ml}$ of CSF, and treatment was started through an iv line placed in a peripheral ear vein. On individual days, groups of six rabbits were examined. The animals were usually assigned to at least three different treatment or control regimens.

Treatment regimens. Antibiotic therapy consisted of a 3-hr constant infusion, beginning $16 \mathrm{hr}$ after infection, with cefotaxime or chloramphenicol. Infusions were started with a bolus injection equivalent to the amount of drug infused per hour. Antibiotics were administered in doses that would achieve the high CSF concentrations necessary for a rapidly bactericidal action $[13,15]$ : cefotaxime was infused at a dosage of $100 \mathrm{mg} / \mathrm{kg}$ per hr and resulted in CSF steady-state concentrations of $\sim 10-15 \mu \mathrm{g} / \mathrm{ml}$ [13]; chloramphenicol was administered at a dosage of $60 \mathrm{mg} / \mathrm{kg}$ per hr and resulted in CSF concentrations of $\sim 12 \mu \mathrm{g} / \mathrm{ml}[13,16]$.

Neutralization of endotoxin in CSF. We examined the neutralization of endotoxin in CSF by polymyxin B, which binds nonspecifically to the lipid A moiety of endotoxin [17], and by a monoclonal antibody directed against lipid A. Starting $16 \mathrm{hr}$ after infection, polymyxin B was infused for $3 \mathrm{hr}$ at a dosage of $5,000 \mathrm{U} / \mathrm{kg}$ per $\mathrm{hr}$, either simultaneously with antibiotic treatment (cefotaxime) or alone. This dosage was chosen because it produced CSF concentrations $(4.0 \pm 1.0 \mathrm{mg} /$ liter $)$ that were effective in reduc- ing the endotoxin activity without reducing the CSF bacterial titers.

The monoclonal antibody was produced by fusion of an Epstein-Barr virus-transformed peripheral monocyte with a human fusion partner. Details of the generation and characterization are described elsewhere [17a]. The IgM antibody was found to bind to lipid A of all 15 strains of $E$. coli and Salmonella tested, including the organism used in this study. The antibody was administered either alone or simultaneously with antibiotic treatment (cefotaxime). Approximately $100 \mu \mathrm{g}$ of antibody was injected twice intracisternally in $0.3 \mathrm{ml}$ of PBS, 16 and $17.5 \mathrm{hr}$ after infection. This quantity of antibody was chosen because it produced concentrations in CSF that, on the basis of in vitro results, would be sufficient to neutralize the amount of endotoxin released by the E. coli.

CSF examination. Bacterial titers in CSF were determined by overnight incubation of serial dilutions on blood agar plates. CSF endotoxin concentrations were determined in twofold serial dilutions of CSF in pyrogen-free water [8]. A commercially available Limulus amebocyte lysate test $\left(\right.$ Pyrotell $^{\mathbf{B}}$; Associates of Cape Cod, Woods Hole, Mass) was used to determine the presence of detectable endotoxin, and the manufacturer's guidelines were observed. The lower limit of detectability of endotoxin was $3 \mathrm{pg} / \mathrm{ml}$. In the monoclonal antibody preparation, the Limulus amebocyte lysate test indicated a minimal endotoxin content of $0.12 \mathrm{ng} / \mathrm{ml}$. No endotoxin activity was detected in the antibiotics tested.

Brain water content (edema). At the end of the experiment, $19 \mathrm{hr}$ after infection, animals were killed by an iv overdose of pentobarbital. As described in detail earlier [18], the brain was immediately removed and dissected on filter paper. One hemisphere was weighed and then dried to stable dry weight in a vacuum oven at $105 \mathrm{C}$. The other hemisphere was dissected into gray and subcortical white matter, and these fractions were also weighed and dried. Brain water content was expressed as grams of water per $100 \mathrm{~g}$ of dry weight. Using these techniques, we found that homologous hemispheres differed by an average of $3.5 \mathrm{~g}$ of water $/ 100 \mathrm{~g}$ of dry weight [18].

Statistics. Results are expressed as mean \pm SD. Paired comparisons of groups were performed by using the two-tailed Student's $t$ test, and multiple comparisons between groups were performed with the Newman-Keuls test [19]. Correlation coefficients 
Table 1. Bacterial titers and endotoxin concentration in CSF associated with brain edema in rabbits with $E$. coli meningitis.

\begin{tabular}{|c|c|c|c|c|c|}
\hline \multirow[b]{2}{*}{ Treatment group $(n)$} & \multicolumn{2}{|c|}{$16 \mathrm{Hr}$ postinfection } & \multicolumn{3}{|c|}{$19 \mathrm{Hr}$ postinfection } \\
\hline & Titer* & Endotoxin $†$ & Titer* & Endotoxin ${ }^{\dagger}$ & Edema $\ddagger$ \\
\hline Uninfected (8) & & & $\ldots$ & & $382 \pm 8$ \\
\hline Infected controls (16) & $4.5 \pm 1.1$ & $1.2 \pm 0.9$ & $5.1 \pm 1.1$ & $1.3 \pm 0.7$ & $389 \pm 8$ \\
\hline Cefotaxime (15) & $5.2 \pm 1.0 \$$ & $1.5 \pm 0.8 \S$ & $2.6 \pm 2.0$ & $2.8 \pm 0.7 \|$ & $405 \pm 12 \|$ \\
\hline Chloramphenicol (7) & $4.6 \pm 0.9$ & $1.0 \pm 0.7$ & $2.7 \pm 2.0$ & $1.5 \pm 0.8$ & $389 \pm 9$ \\
\hline
\end{tabular}

NOTE. Results are expressed as mean $\pm \mathrm{SD}$.

* $\log _{10} \mathrm{cfu} / \mathrm{ml}$.

$\dagger \log _{10} \mathrm{ng} / \mathrm{ml}$.

$\$$ Brain edema, $\mathrm{g}$ of water $/ 100 \mathrm{~g}$ of dry weight.

$\S$ Not significant compared with corresponding values in animals treated with chloramphenicol.

$\| P<.01$ compared with corresponding values in other groups.

were determined by the least-square linear regression method.

\section{Results}

Sixteen hours after intracisternal infection, rabbits showed signs of meningitis, with lethargy, elevated body temperature $(>40 \mathrm{C})$, CSF pleocytosis with a predominance of neutrophils, and positive CSF cultures for $E$. coli $\left(10^{3}-10^{6} \mathrm{cfu} / \mathrm{ml}\right.$; tables 1 and 2$)$. Infection in the subarachnoid space was accompanied by measurable endotoxin concentrations in the CSF, with mean values in the experimental groups ranging from 10 to $100 \mathrm{ng} / \mathrm{ml}$ (tables 1 and 2).

If left untreated, animals had slightly higher titers and endotoxin concentrations in CSF after three additional hours (table 1). By this time (19 hr after infection) animals were killed, and brain water con- tent was determined. Brain water content was higher in infected animals than in uninfected controls (hemispheres, $389 \pm 8$ vs. $382 \pm 8 \mathrm{~g}$ of water $/ 100 \mathrm{~g}$ of dry weight; $P=.08$ ).

Both antibiotics used in the study, cefotaxime and chloramphenicol, reduced CSF bacterial titers to similar degrees when infused for $3 \mathrm{hr}$ (mean reduction, $\log _{10} 2.6$ and $1.9 \mathrm{cfu} / \mathrm{ml}$, respectively; table 1 ). The effect of the two drugs on the endotoxin concentration and brain water content at the end of treatment was, however, markedly different (table 1). Treatment with chloramphenicol was associated with a slight increase of borderline significance $(P<.1)$ in CSF endotoxin concentrations. Treatment with cefotaxime, however, was followed by a much more pronounced increase of endotoxin in the CSF, with final concentrations $\sim 10$ times higher than that obtained with chloramphenicol $(P<.01)$. Chloram-

Table 2. Influence of endotoxin neutralization on brain edema in cefotaxime-treated rabbits with $E$. coli meningitis.

\begin{tabular}{|c|c|c|c|c|c|}
\hline \multirow[b]{2}{*}{ Treatment group (n) } & \multicolumn{2}{|c|}{$16 \mathrm{Hr}$ postinfection } & \multicolumn{3}{|c|}{$19 \mathrm{Hr}$ postinfection } \\
\hline & $\begin{array}{c}\text { Bacterial } \\
\text { titer* }\end{array}$ & Endotoxin ${ }^{\dagger}$ & $\begin{array}{c}\text { Bacterial } \\
\text { titer* }\end{array}$ & Endotoxin ${ }^{\dagger}$ & Edema \\
\hline Uninfected (8) & $\ldots$ & $\ldots$ & $\ldots$ & $\ldots$ & $382 \pm 8$ \\
\hline Infected controls (16) & $4.5 \pm 1.1$ & $1.2 \pm 0.9$ & $5.1 \pm 1.1$ & $1.3 \pm 0.7$ & $389 \pm 8$ \\
\hline Cefotaxime (15) & $5.2 \pm 1.0$ & $1.5 \pm 0.8$ & $2.6 \pm 2.0$ & $2.8 \pm 0.7 \S$ & $405 \pm 12 \S$ \\
\hline Cefotaxime + polymyxin (12) & $5.0 \pm 1.1$ & $1.2 \pm 0.8$ & $2.5 \pm 1.3 \|$ & $0.6 \pm 1.08$ & $392 \pm 8 \S$ \\
\hline Cefotaxime + MAb (11) & $4.8 \pm 1.5$ & $2.0 \pm 1.5$ & $1.2 \pm 1.5 \|$ & $1.6 \pm 1.0 \S$ & $382 \pm 8 \S$ \\
\hline Polymyxin (6) & $4.9 \pm 1.2$ & $1.8 \pm 0.9$ & $4.7 \pm 1.5$ & $1.3 \pm 1.6$ & $395 \pm 10$ \\
\hline MAb (6) & $3.7 \pm 2.3$ & $1.3 \pm 1.0$ & $4.7 \pm 1.8$ & $1.1 \pm 1.1$ & $378 \pm 3$ \\
\hline
\end{tabular}

NOTE. Results are expressed as mean $\pm \mathrm{SD}$.

$* \log _{10} \mathrm{cfu} / \mathrm{ml}$.

$\dagger \log _{10} \mathrm{ng} / \mathrm{ml}$.

$\$$ Brain edema, $\mathrm{g}$ of water $/ 100 \mathrm{~g}$ of dry weight.

$\S P<.01$, cefotaxime vs. others.

\| Not significant. 
phenicol did not induce brain edema above that observed in infected, untreated control animals, whereas treatment with cefotaxime was followed by a significant rise in brain water content (hemispheres, $405 \pm 12$ vs. a mean of 389 in the two other groups; $P<.01$, table 1 ).

Intravenous infusion of polymyxin $B$ for $3 \mathrm{hr}$ produced a bacteriostatic effect on $E$. coli, and CSF endotoxin concentrations and brain water content were similar to untreated, infected controls (table 2). When polymyxin B was infused simultaneously with cefotaxime, the cefotaxime-associated increase of endotoxin in the CSF and the associated possible brain edema were eliminated (table 2).

A similar effect was observed with a monoclonal IgM antibody to lipid $A$. The antibody had no effect on CSF bacterial counts; titers rose from $\log _{10}$ $3.7 \pm 2.3$ to $4.7 \pm 1.8 \mathrm{cfu} / \mathrm{ml}$ between 16 and 19 $\mathrm{hr}$ after infection. During the same period, the measurable endotoxin concentration in CSF decreased, and the final brain water content was reduced (hemispheres, $378 \pm 3 \mathrm{~g}$ of water $/ 100 \mathrm{~g}$ of dry weight; table 2). Injecting the antibody intracisternally during cefotaxime treatment of infected animals reduced both the measurable endotoxin concentration and the brain water content, with the latter reaching values comparable to those in uninfected controls (table 2).

The association of endotoxin release and the development of brain edema was supported by the positive correlation found between CSF endotoxin concentrations $19 \mathrm{hr}$ after infection and the degree of brain edema $(r=.28, n=73 ; P=.03)$. Brain edema predominantly developed in the subcortical white matter. Water content was clearly highest in the white matter of animals treated with cefotaxime alone (267 $\pm 20 \mathrm{~g}$ of water $/ 100 \mathrm{~g}$ of dry weight, compared with $235 \pm 8 \mathrm{~g}$ of water $/ 100 \mathrm{~g}$ of dry weight in uninfected controls; $P<.01$ ), which corresponds to an increase of $14 \%$. Differences in gray matter water content were less pronounced. Nevertheless, animals treated with cefotaxime alone also had the highest water content in gray matter $(445 \pm 18 \mathrm{~g}$ of water $/ 100 \mathrm{~g}$ of dry weight compared with $430 \pm 7 \mathrm{~g}$ of water $/ 100$ $\mathrm{g}$ of dry weight in controls; $P<.06$ ).

\section{Discussion}

This study provides important new information about the pathophysiology of bacterial meningitis and has potential relevance for the therapy of gram- negative bacillary infection. The results suggest that treating $E$. coli meningitis with some, but not all, antibiotics is associated with a marked increase of CSF endotoxin concentrations early after beginning therapy. The endotoxin induces a significant increase in brain edema; this effect can be blocked by selective binding of the lipid A component of endotoxin.

A major focus in the antimicrobial treatment of bacterial meningitis and other serious infections has been the need to achieve a rapid bactericidal action [20-22]. Almost from the beginning of the antibiotic era, however, there has been concern that rapid lysis of gram-negative organisms could be detrimental to the host [23]. Recent work [8-10] has provided evidence for this concern. Antibiotics in vitro, as well as in a rabbit model of gram-negative sepsis, induced marked release of endotoxin. The present study extends these findings to a model of gram-negative bacillary meningitis and correlates the changes in endotoxin concentrations in the CSF with a pathophysiological parameter. The two antibiotics studied differed substantially in their effect on endotoxin concentrations in the CSF. Chloramphenicol, an inhibitor of bacterial protein synthesis, induced only a small increase of endotoxin in our model of meningitis and in the rabbit model of gram-negative sepsis [10]. However, a cell wall-active cephalosporin, cefotaxime in our study and moxalactam in the sepsis model [10], induced a large increase in endotoxin concentration.

Endotoxins are responsible for many of the pathophysiological effects of gram-negative infections (reviewed by Morrison and Ulevitch [11] and by Ryan [24]). The lipopolysaccharide molecules interact with humoral and cellular systems and lead to fever, septic shock, disseminated intravascular coagulation, adult respiratory distress syndrome, and other complications of gram-negative infections. The effect of endotoxin on the brain in gram-negative meningitis has not been previously studied.

Brain edema is a common and potentially fatal complication of bacterial meningitis. In experimental pneumococcal meningitis, we have previously documented a consistent rise in the brain water content as a consequence of the infection in the subarachnoidal space [18]. Treatment with antibiotics or corticosteroids reverses this increase in brain water content [18]. Similar changes in brain water content that are caused by live pneumococci can also be induced by injecting bacterial cell wall products [7]. The present study demonstrates that the apparent liberation 
of endotoxin by antibiotic treatment of $E$. coli meningitis is associated with a dramatic increase in brain water content. This development of brain edema takes place predominantly in the subcortical white matter, a localization that is indicative of vasogenic brain edema [25]. Endotoxin damages endothelial cells directly $[26,27]$ or by stimulating granulocytes [28]. Morphological alterations of the endothelium of the blood-brain barrier (opening of the tight junctions between the endothelial cells) and increased permeability to proteins and fluid are consistent findings in meningitis [29]. In the case of gram-negative meningitis, it is thus likely that endotoxin damages the endothelium of the cerebral capillaries (bloodbrain barrier); this damage subsequently leads to vascular leakage and the development of vasogenic brain edema.

The molecular structure of the endotoxin responsible for the majority of its harmful effects is the lipid A portion of the core region [12, 24]. It is well established that inactivation of lipid A prevents many of the endotoxin-mediated biologic effects in vitro and in vivo. Polymyxin B, a cyclic polypeptide antibiotic that binds to lipid $\mathrm{A}$ [17], has been used successfully to this end [30-33], although not all functions of endotoxin can be neutralized by polymyxin B [34]. In a recent study of experimental meningitis, preincubating polymyxin B of Haemophilus influen$z a e$ type $\mathrm{b}$ lipopolysaccaride reduced the potential of the lipopolysaccharide to induce an inflammation in the CSF [35]. In the present study, polymyxin B prevented the increase, in the CSF, of measurable endotoxin induced by cefotaxime and also reduced the associated increase in brain edema. This finding supports the essential role of endotoxin in the development of brain edema associated with cefotaxime treatment, because polymyxin $B$ alone had no effect.

Antibodies to the glycolipid core region of endotoxin have attracted major attention as tools in the prevention or treatment of the septic complications associated with gram-negative bacteremia $[36,37]$. Because the core region of lipopolysaccarides of different gram-negative bacteria is relatively stable immunologically, antibodies to the core region of one strain are protective against the endotoxin of different strains $[38,39]$. More recently, monoclonal antibodies against the core region of endotoxin have been developed; these antibodies also show cross-reactivity [40]. In this study we used a monoclonal IgM antibody to lipid A with cross-reactivity to lipid A of several E. coli and Salmonella strains (data not shown). Injecting this antibody into the CSF protected against a cefotaxime-associated increase in endotoxin and brain edema. This finding strongly supports the concept that the lipid A portion of endotoxin was responsible for the development of brain edema in our model of $E$. coli meningitis. It is interesting that the monoclonal antibody did not differ from polymyxin B in its capacity to neutralize measurable endotoxin in the CSF, but was clearly more effective in reducing brain water content. This could imply an additional nonspecific effect of the IgM macromolecule beyond its protective action against lipid $\mathrm{A}$. We also found a slight reduction of brain edema with another IgM antibody not directed against endotoxin (data not shown), and these macromolecules may have some hypertonic effects on brain water content.

Our study examined neither the mechanisms responsible for the increase, in CSF, of endotoxin concentrations associated with cefotaxime treatment nor the molecular basis of the effect of polymyxin B or the monoclonal antibody. Moreover, the clinical relevance of our findings is not fully established. Nevertheless, it appears likely that brain edema in bacterial meningitis contributes to morbidity and mortality and that a potentiation by endotoxin may be harmful $[25,41]$. Interestingly, $>50 \%$ of the brain herniations in the series of bacterial meningitis reported by Dodge and Swartz [41] occurred $>2 \mathrm{hr}$ after lumbar puncture, at a time when therapy presumably had been initiated. Conceivably, endotoxininduced brain edema may have played a role in some of these cases. Further studies will be necessary to elucidate the mechanisms responsible for both the increase and inactivation of endotoxin documented in this study and to explore the value of therapeutic strategies that block the release of potentially deleterious bacterial products or inactivate their effect on the host.

\section{References}

1. Swartz MN. Bacterial meningitis. More involved than just the meninges. N Engl J Med 1984;311:912-4

2. Schlech WF, Ward JI, Band JD, Hightower A, Fraser DW, Broome CV. Bacterial meningitis in the United States, 1978 through 1981. JAMA 1985;253:1749-54

3. Cherubin CE, Marr JS, Sierra MF, Becker S. Listeria and gram-negative bacillary meningitis in New York City, 1972-1979. Am J Med 1981;71:199-209 
4. McCracken GH, Threlkeld N, Mize S, Baker CJ, Kaplan SL, Faingezicht I, Feldman WE, Schaad U, Neonatal Meningitis Cooperative Study Group. Moxalactam therapy for neonatal meningitis due to gram-negative enteric bacilli. JAMA 1984;252:1427-32

5. Tuomanen E, Tomasz A, Hengstler $B$, Zak $O$. The relative role of bacterial cell wall and capsule in the induction of inflammation in pneumococcal meningitis. J Infect Dis 1985;151:535-40

6. Tuomanen E, Liu H, Hengstler B, Zak O, Tomasz A. The induction of meningeal inflammation by components of the pneumococcal cell wall. J Infect Dis 1985;151:859-68

7. Täuber MG, Tuomanen E, Zak $O$, Sande MA. Increased intracranial pressure induced by pneumococcal cell wall [abstract no. 683]. In: Program and abstracts of the 25th Interscience Conference on Antimicrobial Agents and Chemotherapy. Washington, DC: American Society for Microbiology, 1985

8. Andersen BM, Solberg $O$. The endotoxin-liberating effect of antibiotics on meningococci in vitro. Acta Pathol Microbiol Scand [B] 1980;88:231-6

9. Shenep JL, Mogan KA. Kinetics of endotoxin release during antibiotic therapy for experimental gram-negative bacterial sepsis. J Infect Dis 1984;150:380-8

10. Shenep JL, Barton RP, Mogan KA. Role of antibiotic class in the rate of liberation of endotoxin during therapy for experimental gram-negative bacterial sepsis. J Infect Dis 1985;151:1012-8

11. Morrison DC, Ulevitch RJ. The effects of bacterial endotoxins on host mediation systems Am J Pathol 1978;93:525-618

12. Berman NS, Siegel SE, Nachum R, Lipsey A, Leedom J. Cerebrospinal fluid endotoxin concentrations in gramnegative bacterial meningitis. J Pediatr 1976;88:553-6

13. Shibl AM, Hackbarth CJ, Sande MA. Evaluation of pefloxacin in experimental Escherichia coli meningitis. Antimicrob Agents Chemother 1986;29:409-11

14. Dacey RG, Sande MA. Effect of probenecid on cerebrospinal fluid concentrations of penicillin and cephalosporin derivatives. Antimicrob Agents Chemother 1974;6:437-41

15. Täuber MG, Doroshow CA, Hackbarth CJ, Rusnak MG, Drake TA, Sande MA. Antibacterial activity of $\beta$-lactam antibiotics in experimental meningitis due to Streptococcus pneumoniae. J Infect Dis 1984;149:568-74

16. Scheld WM, Brodeur JP, Sande MA, Alliegro GM. Comparison of cefoperazone with penicillin, ampicillin, gentamicin, and chloramphenicol in the therapy of experimental meningitis. Antimicrob Agents Chemother 1982;22:652-6

17. Morrison DC, Jacobs DM. Binding of polymyxin B to the lipid A portion of bacterial lipopolysaccharides. Immunochemistry 1976;13:813-8

17a. Pollack M, Raubitschek AA, Larrick JW. Hurnan monoclonal antibodies that recognize conserved epitopes in the core-lipid A region of lipopolysaccharides. J Clin Invest 1987;79:1421-30

18. Täuber MG, Khayam-Bashi H, Sande MA. Effects of ampicillin and corticosteroids on brain water content, cerebrospinal fluid pressure, and cerebrospinal fluid lactate levels in experimental pneumococcal meningitis. $\mathrm{J}$ Infect Dis 1985;151:528-34
19. Zar JH. Biostatistical analysis. 2nd ed. London: Prentice-Hall, 1984:190-1

20. Scheld WM, Sande MA. Bactericidal versus bacteriostatic antibiotic therapy of experimental pneumococcal meningitis in rabbits. J Clin Invest 1983;71:411-9

21. Sande MA. Antibiotic therapy of bacterial meningitis: lessons we've learned. Am J Med 1981;71:507-10

22. McCracken GH. The rate of bacteriologic response to antimicrobial therapy in neonatal meningitis. Am J Dis Child 1972;123:547-53

23. Hopkin DAB. Frapper fort ou frapper doucement: a gramnegative dilemma. Lancet 1978;2:1193-4

24. Ryan JL. Microbial factors in pathogenesis: lipopolysaccharides. In: Root RK, Sande MA, eds. Septic shock. New York: Churchill Livingstone, 1985:13-25

25. Fishman RA. Brain edema. N Engl J Med 1975;293:706-11

26. Harlan JM, Harker LA, Reidy MA, Gajdusek CM, Schwartz SM, Striker GE. Lipopolysaccharide-mediated bovine endothelial cell injury in vitro. Lab Invest 1983;48:269-74

27. Gaynor $\mathbf{E}$. The role of granulocytes in endotoxin-induced vascular injury. Blood 1973;41:797-808

28. Yamada O, Moldow CF, Sacks T, Craddock PR, Boogaerts MA, Jacob HS. Deleterious effects of endotoxin on cultured endothelial cells: an in vitro model of vascular injury. Inflammation 1981;5:115-26

29. Quagliarello VJ, Long WJ, Scheld WM. Morphologic alterations of the blood-brain barrier with experimental meningitis in rats. J Clin Invest 1986;77:1084-95

30. Corrigan JJ, Bell BM. Endotoxin-induced intravascular coagulation. Prevention with polymyxin B sulfate. J Lab Clin Med 1971;77:802-10

31. Palmer JD, Rifkind D. Neutralization of the hemodynamic effects of endotoxin by polymyxin B. Surg Gynecol Obstet 1974;138:755-9

32. Rifkind D, Hill RB. Neutralization of the Shwartzman reactions by polymyxins. J Immunol 1967;99:564-9

33. Dubor F, Dosne AM, Chedid LA. Effect of polymyxin B and colimycin on induction of plasminogen antiactivator by lipopolysaccharide in human endothelial cell culture. Infect Immun 1986;52:725-9

34. Kluger MJ, Singer R, Eiger SM. Polymyxin B use does not ensure endotoxin-free solution. J Immunol Methods 1985;83:201-7

35. Syrogiannopoulos GA, Hansen EJ, Erwin AL, Munford RS, McCracken GH. The role of Haemophilus influenzae type $b$ lipopolysaccharide in the induction of meningeal inflammation [abstract no. 748]. In: Program and abstracts of the $\mathbf{2 6}$ Interscience Conference on Antimicrobial Agents and Chemotherapy. Washington, DC: American Society for Microbiology, 1986

36. Baumgartner J-D, Glauser MP, McCutchan JA, Ziegler EJ, van Melle G, Klauber MR, Vogt M, Muehlen E, Lüthy R, Chiolero R, Geroulanos S. Prevention of gram-negative shock and death in surgical patients by antibody to endotoxin core glycolipid. Lancet 1985;2:59-63

37. Ziegler EJ, McCutchan JA, Fierer J, Glauser M, Sadoff JC, Douglas H, Braude AI. Treatment of gram-negative bacteremia and shock with human antiserum to a mutant Escherichia coli. N Engl J Med 1982;307:1225-30 
38. Braude AI, Douglas H. Passive immunization against the local Shwartzman reaction. J Immunol 1972;108:505-12

39. Johns MA, Bruins SC, McCabe WR. Immunization with $R$ mutants of Salmonella minnesota. II. Serological response to lipid $A$ and the lipopolysaccharide of Re mutants. Infect Immun 1977;17:9-15

40. Gigliotti F, Shenep JL. Failure of monoclonal antibodies to core glycolipid to bind intact smooth strains of Escherichia coll. J Infect Dis 1985;151:1005-11

41. Dodge PR, Swartz MN. Bacterial meningitis-a review of selected aspects. II. Special neurologic problems, postmeningitic complications, and clinicopathological correlations. N Engl J Med 1965;272:954-60 